\title{
Examining the Nuances of Trauma Through a Survivor's Testimony: A Study of A Gift of Goddess Lakshmi: A Candid Biography of India's First Transgender Principal by Manobi Bandyopadhyay with Jhimli Mukherjee Pandey
}

\author{
Pratishi Hazarika \\ Ph.D. Research Scholar, Department of English, Tezpur University, Assam, Email id: \\ pratishihazarika@gmail.com, ORCID id: https://orcid.org/oooo-ooo1-7026-1124
}

\begin{abstract}
The transgender community in India is a marginalized social group that lacks the basic human rights and privileges granted to the cisgender and heterosexual subjects in society. Due to their non-conforming gender and sexual identity, transgender individuals are labeled as deviant, abnormal and diseased in society that has adverse effects on their psyche, making them prone to suicidal thoughts, acute depression and anxiety. This study aims to analyze the trauma endured by transgender individuals and its never-ending effects on their psychological health, through a re-reading of Manobi Bandyopadhyay's biography, titled, A Gift of Goddess Lakshmi: A Candid Biography of India's First Transgender Principal (2017) by Bandyopadhyay with Jhimli Mukherjee Pandey. It shall also explore how the trauma experienced by transgender people in society is of two folds- bodily trauma and mental trauma which demands an integrated approach, as applied in the study. The methodology of close reading of the selected text shall be combined with the framework of trauma psychology and transgender studies, to conduct the study. The significance of this paper rests in the absence of a comprehensive literary study, in the mentioned area.
\end{abstract}

Keywords: Trauma, Transgender people, Stigma, Mental Health

\section{Introduction}

In India, transgender, transsexual and gender non-conforming people have been a part of the cultural landscape, since the ancient times. Yet, the transgender community experiences trauma, abuse and discrimination in their everyday life, within the cultural, economic and political spheres. Due to the dichotomy between their gender identity and sex assigned at birth, transgender individuals remain vulnerable to exploitation and marginalization in society. The victimization of the transgender community on account of their non-normative identity, often results in their deteriorating physical, sexual and mental health. In India, the rate of suicide among transgender individuals is comparatively high than the general population. It is stated to be about $31 \%$, while $50 \%$ of the transgender community has attempted suicide during their adolescence (Virupaksha et al. 2016). Such staggering statistics indicate the health risks among transgender individuals, facing barriers to education, employment, health care and other legal rights in society.

(c) AesthetixMS 2021. This Open Access article is published under a Creative Commons Attribution Non-Commercial 4.0 International License (http://creativecommons.org/licenses/by-nc/4.o/), which permits non-commercial re-use, distribution, and reproduction in any medium, provided the original work is properly cited. For citation use the DOI. For commercial re-use, please contact editor@rupkatha.com. 
The marginalized status of the transgender community materializes through the regulation of various non-conforming bodies, gender identities and sexual practices, legitimized by the hegemonic discourses in society. The regulative process functions through various societal institutions such as family, school, religion, state etc. that helps to sustain the hegemonic order. The present-day victimization of transgender people has its roots in the regulation and criminalization of the hijra population, during the British colonial regime in the nineteenth century. The term "hijra" refers to an individual born biologically male but exhibiting feminine gender traits that situates them in a liminal space, termed as the "third gender" in society. Jessica Hinchy in the text, Governing Gender and Sexuality in Colonial India: The Hijra, c. 1850-1900 (2019), traces the origin of the word "hijra" claimed to be "an Urdu word derived from Persian, probably either from hiz, the Persian root word meaning 'effeminate', or hich, a person who is hichgah or nowhere" (p. 19).

In India, hijras (also known as "kinnar", "tirunangai”, "kothi”, “aravani” etc.) have existed since the Vedic period, when they were revered in society. This is reflected in the concepts of "tritiya prakriti" (meaning, "third nature") and "napumsaka" (meaning, "impotent"), referenced in the Hindu epics, mythological texts, folklores and the ancient Vedic and Puranic scriptures. Even in the Mughal period, hijras held dignified positions, serving as counselors, confidantes and harem guards in the royal court (Konduru \& Hangsing, 2018, p. 12). Aside from their honorable status, hijras performed the "badhai" ritual (meaning, blessings), during marriages and child births, establishing their identity as auspicious beings. Hence, in precolonial India, hijras were considered as an integral part of the socio-cultural landscape. Yet, their status deteriorated around the period of the nineteenth century, when the British colonial rulers began to regulate the gender expression and sexuality of the colonized subjects. Consequently, hijras were penalized through the imposition of laws such as Section 377 of the Indian Penal Code (IPC) of 1861 and the Criminal Tribes Act (CTA) of 1871 (Hinchy, 2019, pp. 2-3). These rulings targeted various gender non-conforming people who were labeled as offenders and criminals, due to their bodies, gender performances, sexual practices and occupations. The criminalization of the transgender community, through the enforcement of laws, validated the violence inflicted on them, in society. This caused a change in the mindset of the general population that began to associate the notions of aberration, abnormality and disease, with the transgender population.

In present day India, the impact of the colonial regulation of hijras is reflected in the prevailing laws and cultural attitudes towards transgender people in society. Jayadeva (2017) mentions that in October, 2013, the Supreme Court of India had directed the Indian states to develop welfare agencies, for the improvement of the medical and health services in regards to the transgender community. However, despite such a ruling, transgender individuals continue to experience exploitation and abuse, while seeking health care, due to the prevalent societal stigma and the lack of expertise in the medical community, to deal with transgender patients. There prevails a dearth of medical studies on hijras and the majority of the studies conducted on the transgender community, focus primarily on HIV/AIDS (Jayadeva, pp. 7-8). Despite the increase in the rate of mental illness and trauma among transgender individuals, limited studies analyze the mental health of transgender people.

The trauma endured by the transgender community is often articulated and represented in the memoirs, biographies and autobiographies of transgender individuals. This paper, through the biography of Manobi Bandyopadhyay titled, A Gift of Goddess Lakshmi: A Candid Biography of India's First Transgender Principal (2017), by Bandyopadhyay with Jhimli Mukherjee Pandey, aims to examine the trauma endured by transgender individuals and its never-ending effects on their 
mental health. It shall also explore how the trauma experienced by transgender people in society is of two folds- bodily trauma and mental trauma that demands an integrated framework of analysis, as applied in the study. The methodology of close reading of the selected text would be combined with the framework of trauma psychology and transgender studies, to conduct the study.

The etymology of the term "trauma" has its roots in Greek, denoting "an injury inflicted on a body" (Caruth, p. 3). The corporeal aspect of the term, however, altered with the interventions of medicine and psychiatry, including the works of Freud that introduced a psychological dimension to trauma, referring to a wound inflicted not on the body, but the mind. Following a similar trajectory, Kai Erikson (1991) claims,

...trauma can result from a constellation of life's experiences as well as from a discrete event-from a prolonged exposure to danger as well as from a sudden flash of terror, from a continuing pattern of abuse as well as from a single assault, from a period of attenuation and wearing away as well as from a moment of shock. (p. 457)

Hence, an individual might develop trauma as a victim of military attacks, as well as, for experiencing social exclusion. Further, the American Psychiatric Association (2013) defines the mental condition of post-traumatic stress disorder (PTSD) as,

a psychiatric disorder that may occur in people who have experienced or witnessed a traumatic event such as a natural disaster, a serious accident, a terrorist act, war/combat, or rape or who have been threatened with death, sexual violence or serious injury. (Torres, 2020)

While, most of the research about PTSD focuses on combat veterans, even transgender people suffer from the mental condition, being subjected to abandonment, exploitation and harassment in society. This is vividly manifested in the biography of Manobi Bandyopadhyay, to be discussed in this study.

\section{Textual Analysis of A Gift of Goddess Lakshmi: A Candid Biography of India's First Transgender Principal by Manobi Bandyopadhyay with Jhimli Mukherjee Pandey}

Manobi Bandyopadhyay's biography titled, A Gift of Goddess Lakshmi: A Candid Biography of India's First Transgender Principal presents the traumatic experiences and struggles, encountered by transgender individuals in their everyday life. Born in 1964, in Chandernagore, Hooghly, Manobi was sex assigned male at birth, and named as Somnath by her parents who desired for a male child, after having two daughters. For her father, Manobi was a "trophy to show off to his family that had ridiculed him all this while for not being able to father a son" (Bandyopadhyay, p. 2). This attitude reflects the patriarchal mindset of society that considers sons as assets, future providers and caretakers for the family; one who shall continue the family line. The contentment of bearing a socalled son, however, converted into disgrace for Manobi's parents, when they observed the "nonnormative" gender identity of their "son". So, to overcome his hurt male ego, Manobi's father refused to acknowledge his son's non-conforming behavior, for a long period of time. Manobi recounts her tragic childhood memory,

...when I was gradually metamorphosing into someone else right in front of his eyes, the whole world noticed, but my father chose to look the other way for as long as he could. (Bandyopadhyay, p. 6) 
This act of denial reflects the prevalent cultural tendency to invalidate the existence of alternative identities. Judith Butler in the text, Gender Trouble: Feminism and the Subversion of Identity (1990), argues that not only gender but even sex is socially constructed (pp. 9-10). This implies that when a sex is applied to a new born child that application is based on how the genitalia is interpreted and regarded in society. So, in Manobi's narrative, when Somnath was born with a penis, it was assumed that he would grow up to be a boy and desire a woman, and he would need the penis to impregnate a woman. Hence, Somnath was destined to be a man in society. The problem with this assumption is identified by Manobi, who transgressed gender boundaries and even underwent corporeal transformation, through sex reassignment surgery.

The non-normative gender expression and sexuality of Manobi, subverts the idealized link between the categories of sex, gender and sexuality. Since childhood, Manobi had imagined herself to be a woman and she fulfilled her inner longing, through the practice of cross-dressing. In the text, Manobi refers to her moment of self discovery as,

So when did I change? When did the so-called metamorphosis happen? It perhaps started with my love for my sister's printed frocks. I would take every opportunity to take off my pants and slip into them...and stand for hours in front of the mirror admiring my looks. (Bandyopadhyay, p. 9)

The sartorial self fashioning conducted by Manobi, enabled her to express and construct her gender identity. However, her corporeal performance posed a threat to the socially constructed gender binary that made Manobi a target of abuse and trauma, inflicted by her family, and the society at large.

Ideally, the space of the home is expected to provide safety and comfort to its residents, but in the context of Manobi, the home was converted into a site of trauma, following the gender policing, stigma and abuse experienced by her, in the familial context. Manobi recollects her traumatic childhood experience as a victim of sexual abuse, when she was sexually assaulted by an older cousin. Manobi describes the traumatic incident as,

He was like a tiger who had tasted human blood, and lurked here and there, trying to corner me every now and then. Gradually it became a routine, both for him and me. (Bandyopadhyay, p. 9)

Following the initial act of child sexual abuse, Manobi engaged in numerous sexual encounters with the same cousin, later on. Such a response to a traumatic incident involving sexual violation might be interpreted as a desperate attempt by Manobi, to seek acceptance from society.

Further, the space of the home became suffused with tensions and conflicts for Manobi, not only due to mental and physical abuse, in the familial context but also, on account of the question of her self-identity. Manobi recounts,

...I was developing a distaste for my genitals. I just couldn't accept my balls and my penis. I wanted to have my sister's genitals... (Bandyopadhyay, p. 8)

This foreshadows the journey she undertakes to become a transwoman. The sense of confusion and suffering, encountered by Manobi, due to her failure to identify with her material body, is represented through her interaction with the self, as reflected in the mirror. Manobi recollects the experience,

I would spend hours standing naked in front of the mirror trying to inspect the image that stared back at me. I hated him. I could not relate one bit to this body that was absolutely 
linear with no curves in sight. Each time I arrived at the same conclusion- this is not me. (Bandyopadhyay, p. 28)

The reflected self of Manobi was distorted, due to the absence of an alignment between her body, gender identity, and body image. Jay Prosser (1998) argues that "the mirror enables in the transsexual only disidentification, not a jubilant integration of body but an anguishing shattering of the felt already formed imaginary body-that sensory body of the body "image'"' (p. 100). This is evident in the text, when Manobi recounts her plight of being misrepresented by the mirror. She states,

My soul and sexuality did not match the image I saw in the mirror. I would look at that otherwise perfect reflection and weep for hours. I felt like tearing away and escaping from the man's body in which I was born. (Bandyopadhyay, p. 109)

The trope of the mirror is essential to the narrative, as it functioned as a significant device that channelized the transition of Manobi, into a transwoman. The advent of "home" for Manobi, materialized only after undergoing sex reassignment surgery, when she managed to assign herself the gender identity with which she internally identified. This experience is manifested in the text, through her encounter with the mirror, during which Manobi declares, "Finally, my soul had found its body, and I had a sense of completeness that had been denied to me at birth" (Bandyopadhyay, p. 136). Hence, for Manobi her transition became the route to corporeal integrity and identity.

Further, the text refers to another transgender individual, named Jolly who underwent a similar crisis with her natal identity, but did not have the privilege to undergo sex reassignment surgery. Belonging to the lower class, Jolly was forced into prostitution by her mother, where she met Chandan, with whom she desired to have a family, but to her dismay, Chandan did not harbor the same feelings. So, in a last-ditch attempt to reconcile her relationship with Chandan, Jolly castrated herself. The act of self-mutilation performed by Jolly could be construed as the effect of her trauma, resulting from rejection. This incident highlights the hazardous methods employed by transgender individuals, to align their natal body with their gender identity. Although, Jolly survives the potentially fatal ordeal, numerous transgender lives succumb to their injuries.

The traumatic encounters in the text extend beyond the realms of the home and family. At school, Manobi became an object of ridicule and abuse, for deviating from the gender specific norms associated with clothes, the use of makeup and accessories. She mentions,

They would pinch me, pull my hair, box my ears and punch my face at the slightest provocation...No one took pity on me. This left a deep scar on my mind. (Bandyopadhyay, p. 8 )

Butler in the text, Bodies That Matter: On the Discursive Limits of "Sex" (1993), argues that the process of subject formation in society is governed by certain regulatory norms. These norms consider only those bodies to be legitimate and normal that conform to the idealized gender traits and sexual practices in society (p. xii). Going by Butler's dictum, the acts of violence and discrimination directed at Manobi, by her peers, represent the attempt to regulate the gender performances and bodies of gender non-conforming individuals, in hetero-patriarchal societies.

As she grew up, the experiences of harassment and discrimination, increased for Manobi. Even after joining college, she was ridiculed, on account of her identity. Manobi describes her predicament as, 
... I could not be called a man or woman and that was far more important than the fact that I had read more Bengali literature than anyone else...Clearly, my reputation had preceded me. (Bandyopadhyay, p. 40)

The lack of educational opportunities for transgender individuals leads to low literacy rates in the community, resulting in the inevitability of sex work. Even if some individuals attempt to overcome the barriers, they are often left traumatized by their subjection to violence and abuse, as apparent in the context of Manobi.

The situation of Manobi worsened after her appointment as a lecturer in a government college, located in a rural village, Jhargram. In her college, Manobi is victimized by two lecturers who believed that "no hijra had the right to become a professor!" (Bandyopadhyay, p. 92). They attempted to persuade their colleagues to ostracize Manobi, whom they considered to be an "aberration" (Bandyopadhyay, p. 93). Further, they even inflicted physical and sexual abuse on her. This traumatic experience is narrated by Manobi as,

They would lurk in every nook and corner and pull my hair and clothes, saying they wanted to see if my hair was real or if I was wearing a wig. Once, two of them pinned me to the wall and groped me, trying to find out what was beneath my clothes... (Bandyopadhyay, p. 94)

For Manobi, the source of her trauma was an amalgamation of physical and mental wounds, inflicted upon her, by society. The incident of abuse at her workplace, left imprints of horror in her mind, so to ensure her safety, Manobi moved to a remote location and lived in isolation, throughout the tenure of her employment.

Further, the text highlights the fact that the exploitation and harassment experienced by transgender individuals, does not terminate with their transition. Even after undergoing the sex change surgery, Manobi remained vulnerable to discrimination and abuse. This is evident from another traumatic account from Manobi's narrative, when she met Arindam and their relationship ended up in a court case. The whole incident was orchestrated by Arindam's brother, when she had refused his advances. Later, both the brothers falsely accused Manobi of being a homosexual and tried to exhort money from her, to withdraw the case. Manobi recalls the incident,

Arindam started his argument by claiming that I was a homosexual man. He argued that I had lied about the sex change and that he could not marry another man because he was straight and I was gay! (Bandyopadhyay, pp. 149-150)

Following the lawsuit, Manobi had to undergo a humiliating ordeal to establish her female identity. The process involved a medical test where a team of doctors examined her genitalia. While referring to this episode, Manobi questions, "Could there be anything more insulting than this?" (Bandyopadhyay, p. 153). Although the incident occurred prior to the verdict by the Supreme Court of India on April 15, 2014, to grant official recognition to hijras, as "third gender", Manobi's experience of exploitation by the state machinery, authenticates the fear of the hijra community, of being subjected to abuse, while claiming their identity.

As represented in the text, transgender individuals also experience discrimination by the medical establishment. Manobi refers to one of her encounters with a psychiatrist, whom she visits for a consultation, regarding the procedure for sex reassignment surgery. However, to her utter shock the psychiatrist attempts to convince Manobi, to repress her identity. Manobi recounts,

The doctor told me that I was completely out of my senses and that I should not even remotely try to go for such a surgery because it would ultimately harm me. He asked me to take such destructive thoughts out of my mind and remain a boy. (Bandyopadhyay, p. 33) 
The response of the psychiatrist depicts the stigma and prejudices among medical professionals about transgender individuals, and their ignorance regarding the health conditions of the transgender community. During another visit to a psychiatrist, Manobi encountered a similar treatment, where her partner, Biman was persuaded by the doctor to terminate their relationship. Biman, on exiting the clinic, looked weary and started vomiting, indicating his revulsion at the thought of uniting with Manobi. Following this incident, Biman severed their bond, leaving Manobi in a traumatic state. Thus, the narrative draws the reader's attention to the apathy towards transgender individuals in society and their inhuman treatment that is justified by the dominant forces, resulting in their deteriorating physical, sexual and mental health.

In Beyond the Pleasure Principle, Freud propounds that unlike the wound on the body, the wound of the mind, cannot be easily healed, since it appears repeatedly in the form of nightmares, inflicting the same wound on the trauma survivor, as experienced during the original event. Hence, the trauma is not situated in the past event alone, but repeats itself in the life of the survivor (Caruth, pp. 3-4). This aspect of trauma materializes in the narrative of Manobi, as she describes the recurring trauma encountered during the later phase in her life, on account of her past experiences. Manobi states,

All my life people have called me hijra, brihannala, napungshak, khoja, launda...Did it pain me? It maimed me... The pain remains but the ache has dulled with time. It visits me in my loneliest hours, when I come face to face with the question of my existential reality. (Bandyopadhyay, p. vii)

This explains the ever-lasting effect of trauma upon transgender individuals that continues to torment and haunt them, even later on in life. The act of narrating the multiple episodes of trauma encountered by Manobi, as a transgender person and a transwoman, in her biography, becomes fundamental to her healing process and self recovery.

\section{Conclusion}

Manobi Bandyopadhyay's biography, challenges the binary classification of sex, gender and sexuality, imposed by the dominant model in society, since it excludes the demands of alternative identities, and contributes to their marginalization in society. Even though the Preamble to the Constitution of India, guarantees equal rights and opportunities to all citizens, without discrimination of any kind, in reality however, much of these commitments are yet to be exercised. Even though, Article 21 of the Indian Constitution grants to all, the 'Right to life and personal liberty', the medical community still discriminates against transgender individuals, violating their right to a life of dignity. This is evident in Manobi's biography, as she encountered stigma, ridicule and prejudice, at the hands of medical professionals, for her refusal to conform to the prescribed societal norms.

The text becomes a testimony of the lived experiences of Bandyopadhyay who despite the sufferings and turmoil, experienced in society, overcomes the hurdles and continues the quest to claim her identity and her rights. Throughout her tumultuous journey, writing serves as a significant medium for her to narrate the traumatic experiences and miseries, endured in society, as a transgender person and a transwoman. In 1995, Manobi published India's first transgender magazine, Abomanob ('Subhuman') that focused on the issues of the transgender community and their rights. Later, she also authored three books titled, Ontohin Ontorin Prositovortika (Endless 
Bondage) (2002), Third Gender in Bengali Literature (2012) and Amar Arjita Naritwa (My Acquired Womanhood) (2019).

Even though Bandyopadhyay acknowledges her privilege, in the discussed biography, her journey cannot be discounted, due to her marginalized identity in society. Her biography becomes significant for providing a nuanced outlook on the lived realities of the transgender community in India, written from a transgender person's point of view. In the text, Bandyopadhyay subdues the human tendency to repress and silence traumatic memories. The text becomes an outlet to express and heal the traumatic events that occurred in her life. The act of narrating one's trauma provides the survivor the agency to control the haunting thoughts that tend to govern the individual's life. It functions as a therapeutic process that enables trauma survivors to overcome the feelings of depression, anxiety, stress, and suicidal thoughts, experienced by them.

In contemporary India, there appears a gradual shift in the perspective of the general population and the state, towards the transgender community. In the text, The Audacity of Pleasure: Sexualities, Literature and Cinema in India (2017), Brinda Bose mentions that "...the evolving relationship of the state with the hijra possess the potential of creating a space for her within it that recognizes her sexual identity without stigmatizing it, and her sexual difference without fetishizing it in a reductive exercise" (p. 135). Despite numerous efforts by the state to acknowledge the issues of the transgender community and to provide them with legal rights, it proves to be a strenuous task, due to the inclination of the state to regulate "non-normative" identities. In April 15, 2014, the Supreme Court of India granted "third gender" status to hijras, not recognized during the initial phase of Manobi's life that multiplied her struggles. Further, another landmark judgement was passed by the Supreme Court of India on 6 September, 2018 to abolish Section 377 of the Indian Penal Code, inching the transgender community towards equal rights, opportunities and privileges, denied to them in society.

\section{References}

Bandyopadhyay, M. and Pandey, J. M. (2017). A Gift of Goddess Lakshmi: A Candid Biography of India's First Transgender Principal. Penguin Random House India.

Bose, B. (2017). The Audacity of Pleasure: Sexualities, Literature and Cinema in India. Three Essays Collective. Butler, J. (1990). Gender Trouble: Feminism and the Subversion of Identity. Routledge.

---. (2017). Bodies That Matter: On the Discursive Limits of "Sex". Taylor \& Francis.

Caruth, C. (1996). Unclaimed Experiences. Trauma, Narrative and History. Johns Hopkins University Press.

Erikson, K. (1991). Notes on Trauma and Community. American Imago, 48 (4), 455-472.

https://www.jstor.org/stable/26303923

Hinchy, J. (2019). Governing Gender and Sexuality in Colonial India: The Hijra, c.1850-190o. Cambridge University Press.

Konduru, D., \& Hangsing, C. (2018). Socio-Cultural Exclusion and Inclusion of Trans-genders in India. International Journal of Social Sciences and Management, 5(1), 10-17. doi:10.3126/ijssm.v5i1.18147

Jayadeva, V. (2017). Understanding the Mental Health of the Hijra Women of India. The American Journal of Psychiatry Residents' Journal. https://doi.org/10.1176/appi.ajp-rj.2017.120504 
9 Examining the Nuances of Trauma Through a Survivor's Testimony: A Study of A Gift of Goddess Lakshmi: A Candid Biography of India's First Transgender Principal by Manobi Bandyopadhyay with Jhimli Mukherjee Pandey

Prosser, J. (1998). Second Skins- The Body Narratives of Transsexuality. Columbia University Press

Torres, F. (2020, August). What Is Posttraumatic Stress Disorder? [Review of the book Diagnostic and Statistical Manual of Mental Disorders, by American Psychiatric Association]. American Psychiatric Association. Retrieved from https://www.psychiatry.org/patients-families/ptsd/what-is-ptsd

Virupaksha, H. G., Muralidhar, D., and Ramakrishna, J. (2016). Suicide and Suicidal Behavior among Transgender Persons. Indian Journal of Psychological Medicine, 38 (6), 505-509. doi: 10.4103/02537176.194908

Pratishi Hazarika is currently a Ph.D. scholar in the Department of English at Tezpur University, Assam. Her discipline of study is English Literature and the title of her working thesis is A Study of Queer Sexualities and "Non-Normative" Desires in American Contemporary Young Adult Fiction. Her research interest is in the areas of Gender and Sexuality Studies, Queer Theory, Queer Studies and Young Adult Literature. She has pursued her Bachelor of Arts Degree (English Honours) and Masters Degree in English Literature from the University of Delhi. 